\title{
Juvenile Huntington disease
}

INSERM

\section{Source}

INSERM. (1999). Orphanet: an online rare disease and orphan drug data base. Juvenile Huntington disease. ORPHA:248111

Juvenile Huntington disease (JHD) is a form of Huntington disease (HD; see this term), characterized by onset of signs and symptoms before 20 years of age. 